\title{
Work, family socioeconomic status, and growth among working boys in Jordan
}

\author{
H Hawamdeh, N Spencer
}

\begin{abstract}
Aims-To describe the work, family socioeconomic characteristics, and growth of a representative sample of working children in Jordan.

Methods-In a cross sectional survey of growth and health, 135 working children (aged 10-16 years) were studied in the areas of Irbid, Jarash, and North Jordan Valley. The children and their parents were interviewed and data collected on length of working week, income earned by the child, duration of work in years, age of starting work, type of work, child's smoking status, and family socioeconomic status.

Results-The mean age of the children was 13.3 years; $14.8 \%$ had started work before the age of 10 and $12.6 \%$ had been working for more than four years. Mean income was 34 Jordanian Dinars but $6.7 \%$ were unwaged; $34 \%$ were working more than 60 hours per week, and $85.9 \%$ more than 40 hours. Monthly income and working hours were positively correlated with the age of the child. There was no correlation between age and smoking status; $37.8 \%$ smoked more than five cigarettes per day. Mean height and weight $\mathrm{z}$ scores were -0.365 and -0.081 of the UK standard respectively. Packed cell volume was within the anaemic range in $34.1 \%$ of children.

Conclusions-In Jordan many children start work at an early age and work long hours for little or no income. Stunting and anaemia are common and many are established smokers. Relevance of these findings for social policy and health care of working children in Jordan and elsewhere is discussed.

(Arch Dis Child 2001;84:311-314)
\end{abstract}

Keywords: work; socioeconomic status; health care; Jordan; smoking; anaemia

The International Labour Organisation estimates that 100-200 million of the world's children are economically active, the majority in less developed countries. ${ }^{1}$ Child labour in industrialised and developing countries is associated with poverty, inadequate educational opportunities, and failure to enforce existing laws and standards.

In Jordan, child labour has become a common phenomenon in the past 10 years. Despite laws prohibiting work among children below the age of 16 years, there were an estimated 100 000-120000 working children in $1993 .^{2}$

Various studies have shown that child labour is primarily driven by family poverty, ${ }^{3-5}$ though others have highlighted additional factors such as the freedom and dignity associated with work. ${ }^{6}$ The child's income can contribute up to $25 \%$ of the family income. ${ }^{7}$ Children from poor families in poor countries tend to start work at an early age; in Pakistan, children frequently start work in carpet factories before the age of 6 years, and in Mexico, many children work with their families in the fields from as young as 4 years. ${ }^{8}$ Working hours tend to be long, with some children working as much as 18 hours per day. ${ }^{9}$

The effects of working on growth and health are less well documented. Distinguishing the effects of work from those of poverty has been problematic; however, a Japanese study showed a $4 \mathrm{~cm}$ difference in height between those who started work before the age of 14 years and those starting after the age of 18 years. ${ }^{8}$ Studies from Israel, ${ }^{10}$ Nigeria, ${ }^{8}$ and India ${ }^{11}$ suggest that working children are at greater risk of stunting.

This cross sectional survey of a representative sample of working children in Jordan describes their working conditions, the socioeconomic characteristics of their families, and their growth. It adds to the body of literature describing the work experience of children and is the first such report based on a representative sample in Jordan.

\section{Materials and methods}

The study was conducted in three Jordanian areas-Irbid, Jarash, and North Jordan Valley - with a combined population of 1 million (20\% of the total population). They contain a wide social range and are broadly representative of economic activity in Jordan, from industry in Irbid to agriculture in Jordan Valley.

DEFINITION OF WORKING CHILD

Waged and unwaged male children aged 10-16 years, employed in economic activity in the study areas and not attending school.

\section{SAMPLE SELECTION}

Key local informants were interviewed to identify the sites and type of occupations undertaken by children in the study areas. Each study area was then systematically mapped to children's workplaces. The researcher $(\mathrm{HH})$ then carried out detailed observation of each study area during daytime and evening hours, recording frequency of different types of child labour. Three broad categories of child labour 
Table 1 Work and family socioeconomic characteristics of the working children

\begin{tabular}{|c|c|c|c|c|}
\hline Work and family socioeconomic characteristics & No. & $\%$ & Mean & $S D$ \\
\hline \multicolumn{5}{|l|}{ Working hours } \\
\hline$\leqslant 40$ & 19 & 14.1 & \multirow[t]{3}{*}{57.1} & \multirow[t]{3}{*}{13.7} \\
\hline $41-60$ & 70 & 51.9 & & \\
\hline$>60$ & 46 & 34.1 & & \\
\hline \multicolumn{5}{|l|}{ Monthly child income (JD) } \\
\hline$\leqslant 30$ & 73 & 54.1 & \multirow[t]{3}{*}{34.0} & \multirow{3}{*}{20.5} \\
\hline $31-50$ & 43 & 31.8 & & \\
\hline$>50$ & 19 & 14.1 & & \\
\hline \multicolumn{5}{|l|}{ Per capita household income (JD) } \\
\hline$\leqslant 41$ & 99 & 73.3 & \multirow[t]{2}{*}{36.44} & \multirow[t]{2}{*}{20.98} \\
\hline$>41$ & 36 & 26.7 & & \\
\hline \multicolumn{5}{|l|}{ House $m$ per capita } \\
\hline$\leqslant 10$ & 34 & 25.2 & \multirow{3}{*}{15.57} & \multirow{3}{*}{6.9} \\
\hline $11-20$ & 70 & 51.9 & & \\
\hline$>20$ & 31 & 23 & & \\
\hline \multicolumn{5}{|l|}{ Father's education } \\
\hline Illiterate & 12 & 8.9 & \multirow[t]{3}{*}{ - } & \multirow[t]{3}{*}{ - } \\
\hline Primary and secondary education & 113 & 83.7 & & \\
\hline Higher education & 10 & 7.4 & & \\
\hline \multicolumn{5}{|l|}{ Mother's education } \\
\hline Illiterate & 36 & 26.7 & \multirow[t]{3}{*}{-} & \multirow[t]{3}{*}{-} \\
\hline Primary and secondary education & 89 & 65.9 & & \\
\hline Higher education & 10 & 7.4 & & \\
\hline
\end{tabular}

Table 2 Pearson correlation of age of working children on work related characteristics and smoking

\begin{tabular}{lcc}
\hline Work related characteristics & Correlation coefficient (age) & p value (two tailed) \\
\hline Working hours/week & 0.393 & $<0.01$ \\
Monthly income & 0.470 & $<0.01$ \\
Job type (industrial, agricultural, service) & -0.010 & $\mathrm{NS}$ \\
Smoking status & 0.090 & $\mathrm{NS}$ \\
\hline
\end{tabular}

were identified: industrial (mainly in Irbid); service and commercial (mainly in Jarash); and agricultural (mainly in North Jordan Valley). Sampling was stratified so that each category of child labour was represented in the study sample in proportion to its size in the three study areas. Sample size was estimated so as to give the study sufficient power to detect mean differences in height $\mathrm{z}$ score at the 5\% level related to duration of working and age of starting work. The stratified study sample of 135 working children included 75 in Irbid (60 in the industrial and 15 in the service sectors), 35 in Jarash (25 in the service and 10 in the industrial sectors), and 25 in the Jordan Valley (all in the agricultural sector). With the prior permission of their employer, working children, who were present at the workplace during sampling recruitment visits, were enrolled into the study. Three of 64 employers $(4.7 \%)$ refused permission. No children or parents refused to participate once the purpose of the study had been explained and parents were reassured that the researcher was not a government official. During the pilot study, some difficulty with consent had been experienced but this was overcome once a full explanation of the study was made. The same explanation was used in main study. Two mothers refused height measurement.

DATA COLLECTION

Working children were initially interviewed at the workplace and subsequently in the home with their parents, using a structured interview schedule pretested in a pilot study.

The following data were collected:

(1) Work related variables: length of working week in hours, monthly income earned by the child in Jordanian Dinars (JD), duration of work in years, age in
Table 3 Health related characteristics of the working children

\begin{tabular}{|c|c|c|c|c|}
\hline Variable & Number & $\%$ & Mean & $S D$ \\
\hline \multicolumn{5}{|l|}{ Smoking status } \\
\hline$\geqslant 5 /$ day & 51 & $37.8 \%$ & - & - \\
\hline$<5 /$ day & 84 & $62.2 \%$ & & \\
\hline \multicolumn{5}{|l|}{ Wt/age z score } \\
\hline$>(2 \mathrm{SD})$ & 1 & $0.7 \%$ & -0.081 & 1.13 \\
\hline $1-(2 \mathrm{SD})$ & 20 & $14.9 \%$ & & \\
\hline $0-(1 \mathrm{SD})$ & 50 & $37.0 \%$ & & \\
\hline (0 SD) & 2 & $1.5 \%$ & & \\
\hline $0-(-1 \mathrm{SD})$ & 30 & $22.2 \%$ & & \\
\hline$-1-(-2 \mathrm{SD})$ & 25 & $18.5 \%$ & & \\
\hline$<(-2 \mathrm{SD})$ & 7 & $5.2 \%$ & & \\
\hline \multicolumn{5}{|l|}{$\mathrm{Ht} / \mathrm{age} \mathrm{z}$ score } \\
\hline$>(2 \mathrm{SD})$ & 1 & $0.7 \%$ & & \\
\hline $1-(2 S D)$ & 14 & $10.4 \%$ & & \\
\hline $0-(1 \mathrm{SD})$ & 44 & $32.6 \%$ & & \\
\hline (0 SD) & 00 & $0.0 \%$ & -0.365 & 1.21 \\
\hline $0-(-1 \mathrm{SD})$ & 33 & $24.4 \%$ & & \\
\hline$-1-(-2 \mathrm{SD})$ & 30 & $22.3 \%$ & & \\
\hline$(-2 \mathrm{SD})$ & 13 & $9.6 \%$ & & \\
\hline \multicolumn{5}{|c|}{ Packed cell volume } \\
\hline $29-35^{\star}$ & 46 & $34.6 \%$ & 37.05 & 3.71 \\
\hline$\geqslant 36$ & 87 & $65.4 \%$ & & \\
\hline
\end{tabular}

^Anaemic range.

years of starting work, type of work (industrial, service, or agricultural)

(2) Family socioeconomic status: household monthly per capita income (JD), father's education level, mother's education level, area of the house in square metres

(3) Growth: height in $\mathrm{cm}$, measured using a portable tape, expressed as a $\mathrm{z}$ score using LMS software based on UK standards ${ }^{12}$; weight in $\mathrm{kg}$, measured using Detecto adult scales, expressed as a $\mathrm{z}$ score using LMS software based on UK standards ${ }^{12}$

(4) Health status: smoking-regular smoker (five or more cigarettes per day; yes/no); packed cell volume-measured by standard microhaematocrit method.

ANALYSIS

Frequencies and means with standard deviations were calculated for all groups of variables. Simple correlation of age on work related variables was calculated using analysis of variance. All data analysis was carried out using SPSS version $8.0 .^{13}$

\section{Results}

Table 1 summarises frequencies and means of work related and family socioeconomic status variables. The working children tend to be from low income families. The mean household per capita income was low compared with the Jordanian population (41JD). ${ }^{14}$ A total of $73.3 \%$ of households had a per capita income below 41JD per month. Parental education was generally low in this sample compared with rates for the Jordanian population, ${ }^{15}$ with high levels of maternal illiteracy $(26.7 \%$ in the sample compared with $18.4 \%$ in the whole population) and paternal illiteracy $(8.9 \%$ in the sample compared with $6.5 \%$ in the whole population). A total of $76.3 \%$ of children started work at or before the age of $11 ; 12.6 \%$ had been working for more than four years at the time of the survey, and $34 \%$ of children worked more than 60 hours per week, many of them in industrial jobs. Monthly incomes were 
low: $6.7 \%$ were unwaged and over $50 \%$ earned less than 30JD per month. The child's income contributed $0-25 \%$ of household income. Monthly income and working hours were positively correlated with the age of the working child (see table 2).

Smoking was common among these children; $37.8 \%$ were smoking more than five cigarettes per day (see table 3). Stunting was common; the height $\mathrm{z}$ score was at least $-1 \mathrm{SD}$ in $31.9 \%$ and less than -2 SD in $9.6 \%$. The mean height $\mathrm{z}$ score was -0.365 of the mean for UK children. Wasting was less frequent; the mean weight $\mathrm{z}$ score was -0.081 of the UK mean and only $5.2 \%$ had weight $\mathrm{z}$ scores less than $-2 \mathrm{SD}$. A total of $34.1 \%$ of children had a packed cell volume of $35 \%$ or less, within the anaemic range.

\section{Discussion}

Jordan underwent rapid development during the 1970s and 1980s. Child health status improved dramatically. ${ }^{14}$ As a result of economic problems and the influx of large numbers of refugees, economic pressures on the population have increased during the past 10 years. The findings of this survey suggest that many of the estimated 100 000-120 000 Jordanian working children start work before the age of 11 years and work long hours for little income. Stunting and anaemia are common and many are already established smokers. Family poverty is common among this sample of working children and levels of parental illiteracy and poor education are high. The working children contribute as much as $25 \%$ of the household income.

This is the first systematic survey of a representative sample of working children in Jordan. Apart from a published survey of child labour in Israel, ${ }^{10}$ there is very little published work on child labour in the Middle East. The findings of this survey are consistent with the literature although, as a consequence of higher levels of poverty, working conditions for children in the Indian subcontinent are harsher.

About $34 \%$ of the Jordanian children work more than 60 hours but the correlation of working hours with age suggests that most of these are over 14 years of age. By contrast, children, some as young as 5 years, work up to 80 hours a week in carpet factories in Pakistan. ${ }^{8}$

The high prevalence of stunting and anaemia noted in this survey is consistent with previous studies showing poor nutritional and growth status among working children in various countries. ${ }^{81011}$ Wasting was not prevalent in this sample, but has been noted in studies in Jaipur $^{12}$ and Hyderabad. ${ }^{11}$

Although the survey attempted to identify a representative sample of working children, it is likely that the sample does not fully represent the extent of child labour in Jordan. Child labour is illegal in many countries, including Jordan, although the law is not enforced. As a consequence, children's work is frequently hidden, making the selection of a representative sample difficult. Despite the systematic sampling method used in this study, it is probable that some types of child labour are under represented. The refusal of three employers to allow children in their employment to be interviewed may have excluded a group of children experiencing a harsher work regime. It is likely that child labour within the family is under represented. Impairment of growth may be less likely in the relatively protected family environment. However, more hidden forms of child labour outside the family in less protected environments are also likely to be under represented, and these forms of labour may carry an increased risk of nutritional and growth impairment. In addition, the survey relies on accurate reporting and recall by children and parents of work related and family socioeconomic characteristics. It is possible that there has been systematic under reporting of some work related and family socioeconomic characteristics. It is impossible to verify such details in a survey of this nature and some caution should be exercised in interpreting the results.

Despite these limitations, the survey presents strong evidence suggesting that child labour in Jordan is associated with young age of starting work, long working hours, and low wages. Stunting and anaemia, though not wasting, are common among these children, and prevalence of smoking is high.

The implications of these findings for social and health policy in Jordan are considerable. A large number of Jordanian children are working long hours from an early age, excluding them from participation in education beyond the primary level and exposing them to the hazards of work before they have reached physical and mental maturity. Many children are working to supplement low household incomes. It is likely that their exclusion from regular education will perpetuate the cycle of disadvantage, condemning them to low income and subliteracy similar to that of their parents.

Jordan has strict laws prohibiting child labour but, as in many other countries including the USA and the UK, these are not enforced. Child labour is a deep rooted phenomenon globally, flourishing among poverty and low levels of education. Innovative national and international approaches to reducing the impact of child labour are likely to require a three pronged strategy: social policies aimed at reducing poverty and ensuring basic levels of literacy; legal enforcement where possible; and educational and nutritional outreach to child workers to ensure adequate nutrition and basic literacy.

1 Habenicht $\mathrm{H}$. The international programme on the elimination of child labour: an international response to child abour. International Child Health: a digest of current information $1994 ; \mathbf{V}(2): 19-25$.

2 UNICEF. Diversity in the level and distribution of child labour: a preliminary survey of income substitution and basic education interventions to ameliorate the effects of child labour in the MENA region. New York: UNICEF, 1996:5.

3 Banerjee SR. Child labor in suburban areas of Calcutta, West Bengal. Indian Pediatr 1991;28:1039-44.

Meenakshi NM, Prabhu SV, Mistry HN. Child labor in Bombay. Child Abuse Negl 1985;9:107-11.

5 Asogwa SE. Sociomedical aspects of child labour in Nigeria. f Occup Med 1986;28:46-8.

6 Maheshwari RK, Karunakaran M, Bhandari SR. Child Maheshwari RK, Karunakaran M,
labour. Indian Pediatr 1986;23:701-4.

7 Mian AA. Child labour in Pakistan: a study in the Lahore area. Child Welfare 1991;LXX,2:261-7. 
8 Shah PM. The health care of working children. Child Abuse Negl 1984;8:541-4

9 Sampa M. A study of the health conditions of child workers in a small scale leather industry in Calcutta. $B r f$ Ind $M e d$ 1993;50:938-40.

10 Ellen F, Janice W. Walk-through surveys of child labor. $A m \mathcal{F}$ Ind Med 1994;26:803-7.

11 Satayanarayana K, Prasanna KT, Narasinga RBS. Effect of early childhood undernutrition and child labour on growth and adult nutritional status of rural Indian boys around Hyderabad. Hum Nutr Clin Nutr 1985;40:131-9.

12 Joshi SK, Sharma P. Peak expiratory flow rate of carpet weaving children. Indian Pediatr 1996;33:105-8.

13 SPSS for Windows, version 8.0. Chicago: SPSS Inc., 1998

14 UNICEF. The State of the Fordanian Child 1992-3. Amman: UNICEF Jordan Programme, 1993.

15 Department of Health. Annual statistical book, 1999. Hashimate Kingdom of Jordan, 1999.

\section{Commentary}

It is perhaps not too much of a surprise that working boys in Jordan were stunted, smoked cigarettes, and were anaemic while working long hours. One would anticipate that they might have a higher incidence of tuberculosis and other lung diseases related to the conditions in which they work, as well perhaps as skin, ear, and eye infections if the conditions were overcrowded. It would be interesting to know of their mental health-did they have higher self esteem as a result of being in paid employment, or lower because of bad work conditions? Hawamdeh and Spencer are to be congratulated on their perspicacity in locating and interviewing 135 working boys and their parents. Only three employers of 64 declined consent for interview, suggesting that they were not concerned about the consequences, so it would appear that the law is not well enforced. I would like to have heard the comments of the children on their work; perhaps this would have been difficult to obtain honestly in the presence of the parents. Were there no girl workers? In a Muslim country they would not be allowed to go out to work but drudgery in the kitchen could be just as hard, and child wives at 12 upwards could face a life of labour in more than one way.

The paper raises three questions in my mind: What are the broader health effects of child labour? What is the role of health services in countries in which child labour is widespread? And what is the role of paediatricians internationally on this question?

Worldwide there are about 250 million child labourers, working long hours in often hazardous circumstances. According to Parker, ${ }^{1}$ studies on their health tend to include only small sample sizes and have design flaws. $\mathrm{He}$ describes a high incidence of occupation related disease in countries where there are few health and safety regulations. Working children are likely to suffer from diseases of poverty since they are drawn from the marginalised in society. Families with working children may be better off than those without, so may be somewhat protected in this respect. There would seem to be a need for more research, including mental health aspects and the views of the children themselves.

Additionally, loss of school experience will in itself have health disbenefits, particularly for girls and for their future children.

What role do the health services have in countries such as Jordan, where child labour is widespread? This is primarily a public health issue where there is a sore need for regulation. UNICEF $^{2}$ believes that legislators should distinguish between work that is beneficial and work that is intolerable. The latter relates to hours of work, age of starting, low pay, too much responsibility, loss of education, bad conditions, and undermining of dignity. So the role of health services could be detection, awareness raising, standard setting, and advocacy.

Because there are many linkages between developed and developing countries in relation to child labour, paediatricians need to be aware of the problems and consider our own role. Is there child labour in our own countries? In the USA, immigrant children work long hours in farms in New York State and are exposed to pesticides $^{2}$; in the UK, children may work all day in a shop. Do we disseminate information about the western firms ${ }^{3}$ which exploit children in developing countries? The UN Convention on the Rights of the Child is as applicable in the $\mathrm{UK}$ as the rest of the world ${ }^{4}$ : do we make use of its contents and does our organisation speak out in relation to abuses?

Child labour is a form of child abuse, but families' survival may depend on the earnings of their children. Solutions should be comprehensive, ${ }^{2}$ and should involve the elimination of hazardous child labour and the provision of free education with wider legal protection. Paediatricians have an important role in data collection and in advocacy.

TONY WATERSTON

Newcastle-upon-Tyne

1 Parker D. Health effects of child labour. Lancet 1997;350:1395-6.

2 UNICEF. State of the world's children, 1997. Oxford: Oxford University Press, 1997.

4 www.ethicalconsumer.org $\mathrm{M}$, Burr S, et al. Who is speaking Aynsley-Green A, Barker M, Burr S, et al. Who is speaking
for children and adolescents and for their health at the for children and adolescents and for
policy level? $B M \mathcal{7} 2000 ; 321: 229-32$. 